\begin{tabular}{|lcc|}
\hline & Uniqbu Journal Of Social Sciences (UJSS) \\
\hline Volume 1 & Nomor 1, April 2020 & Halaman 1-12 \\
\hline
\end{tabular}

\title{
ALIH KODE DAN CAMPUR KODE PADA NOVEL BADAI MATAHARI ANDALUSIA KARYA HARY EL-PARSIA (Transfer code and mix code in Novels Badai Matahari Andalusia Karya Hary El-Parsia)
}

\author{
Muhammad Yusnan ${ }^{a}$, Kamasiah $^{\text {b }}{\text { Risman Iyec, } \text { Karim }^{d} \text {, Harziko }}^{\mathrm{e}}$ Riki Bugis $^{\mathrm{f}}$

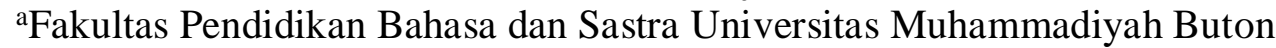 \\ bYIPQ Sekolah Tinggi Agama Islam Baubau

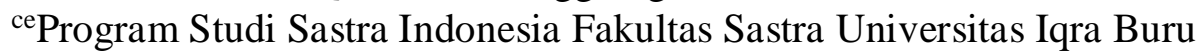 \\ dinstitut Agama Islam Negeri Kendari \\ Pos-el: rismaniye@gmail.com
}

(Diterima: 11 April; Direvisi 19 April; Disetujui: 20 April 2020)

\begin{abstract}
The language produced by speakers is a reflection of a culture that it adheres to because, in communication, it certainly has a close relationship with the other person so that the language spoken can be well understood. A discussion can take place if the style used can be followed so that the message delivered can be received. This study aims to analyze code-switching and code-mixing in novels Badai Matahari Creation Hary El-Parsia. The method in this research is descriptive qualitative carried out by not prioritizing the numbers but prioritizes the depth of appreciation of the interaction between the concepts being studied imply. The type of research in the literature is. The source and type of data of this research are the data written on novel Badai Matahari Andalusia. The results of the study showed that in the Solar Storm novel, there were seven quotes from the Code and nine quotes from the Code. Code Transfer and Mix The most dominant code is the Transfer of Code by mixing Indonesian, English, Arabic. In other words, the author Hary El-Parsia in his work uses the Transfer of Code and Mixed Code as the hallmark of his work.
\end{abstract}

Keywords: Code Transfer, Code Combination. Novel. Badai Matahari Andalusia

\begin{abstract}
Abstrak
Bahasa yang dihasilkan oleh penutur merupakan cerminan suatu budaya yang dianutnya, sebab dalam berkomunikasi tentu memiliki hubungan erat dengan lawan tutur agar bahasa yang diucapkan dapat dipahami dengan baik. Sebuah komunikasi dapat berlangsung apabila bahasa yang diguakan dapat dipahami sehingga pesan yang disampaikan dapat diterima. Penelitian ini bertujuan untuk menganalisis alih kode dan campur kode Pada Novel Badai Matahari Andalusia Karya Hary El-Parsia. Metode dalam penelitian ini adalah deskriptif kualitatif dilakukan dengan tidak mengutamakan angka-angka, tetapi mengutamakan kedalaman penghayatan terhadap interaksi antara konsep yang sedang dikaji secara impiris. Adapun jenis penelitian dalam adalah kepustakaan. Sumber dan jenis data penelitian ini adalah data tertulis pada novel Badai Matahari Andalusia Karya Hary El-Parsia. Hasil penelitian menunjukan bahwa pada novel Badai Matahari terdapat 7 kutipan Alih Kode dan 9 kutipan Campur Kode. Alih Kode dan Campur Kode yang menononjol digunakan adalah Alih Kode dengan mencampurkan bahasa Indonesia, bahasa Inggris bahasa arab. Dengan kata lain pengarang Hary ElParsia dalam karyanya menggunakan Alih Kode dan Campur Kode sebagai ciri khas karyanya..
\end{abstract}

Kata-kata kunci: Alih Kode, Campur Kode. Novel. Badai Matahari Andalusia 


\section{PENDAHULUAN}

Sebuah komunikasi dapat berlangsung apabila bahasa yang diguakan dapat dipahami sehingga pesan yang disampaikan dapat diterima. Apabila seseorang ingin menyatakan maksud, baik kepada orang lain atau diri sendiri maka sudah dapat dikatakan menggunakan komunikasi. Dalam suatu msayarakat tidak mungkin dapat berkomunikasi apabila anggota masyarakat tersebut tanpa menggunakan bahasa sebagai media atau sarananya. Bahasa adalah alat komunikasai yang yang sangat dibutuhkan dan memagang peranan penting sebagai ekspresi jiwa yang ada. Tanpa adanya sebuah bahasa maka kita tidak akan bisa berkomunikasi dan menukarkan pikiran kita dengan orang lain. Terutama bagi para manusia. Bahasa sangat dibutuhkan dalam proses interaksi untuk menukar pikiran maupun saling menyamakan pendapat.

Bahasa tidak dapat dipisahkan dari kehidupan manusia. Dimanapun ada manusia maka disitu juga akan ada komunikasi. Melalui bahasa inilah akan menunjukkan seperti apa karekteristik para penggunanya. Karena bahasa merupakan ekspresi jiwa dari penuturnya. Samsuri (dalam Taufik: 2016) menyatakan bahasa dapat mengungkapkan aspek-aspek sosial yang dimiliki oleh lingkungan sosialnya. Bahasa itu tidak terpisah oleh manusia dan selalu mengikuti di setiap pekerjaanya, karena bahasa alat yang dipakai untuk membentuk pikiran, perasaan, keinginan, dan perbuatannya.

Dalam kenyataannya manusia selalu melakukan kegiatan komikasi dari satu orang kepada orang lain. Hal ini bertujuan untuk mendapatkan informasi dan selalu berusaha mencari sesuatu yang dibutuhkan. Seperti halnya masyarakat yang berkomunikasi dalam bidang ekonomi, budaya, agama dan bidang sosial yang lainnya. Melalui kegiatan sosial inilah akan sangat besar peluang yang diperoleh para anggota masyarakat untuk menggunakan bahasa sebagai alat komunikasinya. Dengan adanya komunikasi dari satu masyarakat ke masyarakat lain maka akan terciptalah kemampuan berbahasa yang beraneka ragam.

Rahardi (2011: 3) menyatakan bahwa dalam bidang bahasa, kenyataan tersebut mengakibatakan semakin bervariasinya kode-kode yang dimiliki dan dikuasai oleh anggota masyarakat itu. Sebagai bukti kemajemukan masyarakat dalam bidang bahasa yaitu terdapat banyak individu yang, memiliki dan menguasai banyak bahasa (multilingual) atau sedikitnya dua bahasa (bilingual).

Berkaitan dengan pennguasaan dalam menggunakan bahasa maka dalam hal ini akan membahas tentang pemakaian dua bahasa atau bilingual. Suwito (Rahardi, 2011: 3) menyebutkan bahwa perkodean sebenarnya meliputi berbagai hal, misalnya campur kode, interferensi, integrasi kode, alih kode, dan sebagainya. Karena terdapat banyak kemampuan bilingualisme maka peneliti akan menitik beratkan pada campur kode. Terutama tentang campur kode bahasa Arab yang terdapat dalam novel Badai Matahari Andalusia Karya Hary El-Parsia. Ragam bahasa yang muncul karena pengaruh sosial budaya yang ada dalam masyarakat.

Berdasarkan latar belakang di atas maka yang menjadi permasalahan pada penelitian ini adalah bagaimana alih kode dan campur kode pada novel Badai Matahari Andalusia Karya Hary El-Parsia?

\section{LANDASAN TEORI \\ Alih Kode dan Campur Kode}

Ohoiwutun (2007:71) mengatakan alih kode (code switching), yakni peralihan pemakaian dari suatu bahasa atau dialek ke bahasa atau dialek lainnya. Alih bahasa ini sepenuhnya terjadi karena perubahanperubahan sosiokultural dalam situasi berbahasa. Perubahan-perubahan yang dimaksud meliputi faktor-faktor seperti hubungan antara pembicara dan pendengar, variasi bahasa, tujuan berbicara, topik yang 
dibahas, waktu dan tempat berbincang. Lebih lanjut Apple dalam Chaer (2004:107) mengatakan, alih kode yaitu gejala peralihan pemakaian bahasa karena berubahnya situasi.

Ditambahkan oleh Hymes (dalam Taufik: 2016) bahwa alih kode bukan hanya terbagi antar bahasa, tetapi dapat juga terjadi antar ragam-ragam atau gaya-gaya yang terdapat dalam satu bahasa. Sebagai contoh peristiwa peralihan yang terjadi dalam suatu kelas yang sedang mempelajari bahasa asing (sebagai contoh bahasa Inggris). Di dalam kelas tersebut secara otomatis menggunakan dua bahasa yaitu, bahasa Indonesia dan bahasa Inggris. Kemudian terjadi percakapan dalam suatu bahasa nasional (contoh bahasa Indonesia) lalu tiba-tiba beralih ke bahasa daerah (contoh bahasa Sumbawa), maka kedua jenis peralihan ini juga disebut alih kode.

Kemudian gejala lain yaitu campur kode. Gejala alih kode biasanya diikuti dengan gejala campur kode, Thelander (dalam Chaer, 2004:115) mengatakan apabila didalam suatu peristiwa tutur terdapat klausa-klausa atau frase-frase yang digunakan terdiri dari klausa dan frase campuran (hybrid clauses, hybrid phrases), dan masing-masing klausa dan frase tidak lagi mendukung fungsi sendiri-sendiri, maka peristiwa yang terjadi ini adalah campur kode.

Nababan (2004:32) mengatakan campur kode, yaitu suatu keadaan berbahasa lain ialah bilamana orang mencampur dua (atau lebih) bahasa atau ragam bahasa dalam suatu tindak bahasa tanpa ada sesuatu dalam situasi berbahasa yang menuntut percampuran bahasa itu. Maksudnya adalah keadaan yang tidak memaksa atau menuntut seseorang untuk mencampur suatu bahasa ke dalam bahasa lain saat peristiwa tutur sedang berlangsung. Jadi penutur dapat dikatakan secara tidak sadar melakukan percampuran serpihan-serpihan bahasa ke dalam bahasa asli. Campur kode serupa dengan interfensi dari bahasa satu ke bahasa lain.
Campur kode penutur menyelipkan unsur-unsur bahasa lain ketika sedang memakai bahasa tertentu. Unsur-unsur tersebut dapat berupa kata-kata, tetapi dapat juga berupa frase atau kelompok kata. Jika berwujud kata biasanya gejala itu disebut peminjaman. Hal yang menyulitkan timbul ketika memakai kata-kata pinjaman tetapi kata-kata pinjaman ini sudah tidak dirasakan sebagai kata asing melainkan dirasakan sebagai bahasa yang dipakai. Sebagai contoh si A berbahasa Indonesia. Kemudian ia berkata "sistem operasi komputer ini sangat lambat". dari sini terlihat si A banyak menggunakan kata-kata asing yang dicampurkan kedalam bahasa Indonesia. Namun ini tidak dapat dikatakan sebagai gejala campur kode atau pun alih kode. Hal ini disebabkan penutur jelas tidak menyadari kata-kata yang dipakai adalah kata-kata pinjaman, bahkan ia merasa semuanya merupakan bagian dari bahasa Indonesia karena proses peminjaman tersebut sudah terjadi sejak lama.

Lebih lanjut Sumarsono (2004:202) menjelaskan kata-kata yang sudah mengalami proses adaptasi dalam suatu bahasa bukan lagi kata yang megalami gejala interfensi, bukan pula alih kode, apalagi campur kode. akan berbeda jika penutur secara sadar atau sengaja menggunakan unsur bahasa lain ketika sedang berbicara dalam suatu bahasa. Peristiwa inilah yang kemudian disebut dengan capur kode. Oleh karena itu dalam bahasa tulisan, biasanya unsur-unsur tersebut ditunjukkan dengan menggunakan garis bawah atau cetak miring sebagai penjelasan bahwa si penulis menggunakannya secara sadar.

\section{Penyebab terjadinya Alih Kode dan Campur Kode}

Penyebab Terjadinya Alih Kode

Selain sikap kemultibahasaan yang dimiliki oleh masyarakat tutur, terdapat beberapa faktor yang menyebabkan terjadinya peristiwa alih kode, seperti yang dikemukakan Chaer (2004:108), yaitu: 


\section{Penutur}

Perilaku atau sikap penutur, yang dengan sengaja beralih kode terhadap mitra tutur karena tujuan tertentu. Misalnya mengubah situasi dari resmi menjadi tidak resmi atau sebaliknya. Kemudian ada juga penutur yang mengharapkan sesuatu dari mitra tuturnya atau dengan kata lain mengharapkan keuntungan atau manfaat dari percakapan yang dilakukanya. Sebagai contoh, A adalah orang sumbawa. B adalah orang batak. Keduanya sedang terlibat percakapan. Mulanya si A berbicara menggunakan bahasa Indonesia sebagai pembuka. Kemudian ditanggapi oleh B dengan menggunakan bahasa Indonesia juga. Namun ketika si A ingin mengemukakan inti dari pembicaraannya maka ia kemudian beralih bahasa, yaitu dari bahasa Indonesia ke bahasa Batak. Ketika si A beralih menggunakan bahasa Batak yang merupakan bahasa asli B, maka B pun merespon A dengan baik. Maka disinilah letak keuntungan tersebut. A berbasa basi dengan menggunakan bahasa Indonesia, kemudian setelah ditanggapi oleh $\mathrm{B}$ dan ia merasa percakapan berjalan lancar, maka si A dengan sengaja mengalihkan ke bahasa batak. Hal ini disebabkan si A sudah ingin memulai pembicaraan yang lebih dalam kepada si B. Selain itu inti pembicaraan tersebut dapat tersampaikan dengan baik, karena mudah dimengerti oleh lawan bicara yaitu B. Peristiwa inilah yang menyebakan terjadinya peristiwa alih kode.

\section{Lawan Tutur}

Mitra tutur atau lawan tutur dapat menyebabkan peristiwa alih kode. Misalnya karena si penutur ingin mengimbangi kemampuan berbahasa lawan tuturnya. Dalam hal ini biasanya kemampuan berbahasa si lawan tutur kurang atau agak kurang karena mungkin bahasa tersebut bukan bahasa pertamanya. Jika lawan tutur yang latar belakang kebahasaannya sama dengan penutur biasanya beralih kode dalam wujud alih varian (baik regional maupun sosial), ragam, gaya, atau register. Kemudian bila lawan tutur berlatar belakang kebahasaan berbeda cenderung alih kode berupa alih bahasa. Sebagai contoh, Rani adalah seorang pramusaji disebuah restoran. Kemudian Ia kedatangan tamu asing yang berasal dari Jepang. Tamu tersebut ingin mempraktikkan bahasa Indonesia yang telah Ia pelajari. Pada awalnya percakapan berjalan lancar, namun ketika tamu tersebut menanyakan biaya makanya Ia tidak dapat mengerti karena Rani masih menjawab dengan menggunakan bahasa Indonesia. Melihat tamunya yang kebingungan tersebut, secara sengaja Rani beralih bahasa, dari bahasa Indonesia ke bahasa Jepang sampai tamu tersebut mengerti apa yang dikatakan Rani. Dari contoh di atas dapat dikatakan telah terjadi peristiwa peralihan bahasa atau disebut alih kode, yaitu bahasa Indonesia ke bahasa Jepang. Oleh karena itu lawan tutur juga sangat mempengaruhi peristiwa alih kode.

\section{Hadirnya orang ketiga}

Kehadiran orang ketiga atau orang lain yang tidak berlatar belakang bahasa yang sama dengan bahasa yang sedang digunakan oleh penutur dan lawan tutur dapat menyebabkan peristiwa alih kode. Untuk menetralisasi situasi dan menghormati kehadiran mitra tutur ketiga, biasanya penutur dan mitra tutur beralih kode, apalagi bila latar belakang kebahasaan mereka berbeda. Sebagai contoh, Tono dan Tini bersaudara. Mereka berdua adalah orang Sumbawa.

Oleh karena itu, ketika berbicara, mereka menggunakan bahasa yang digunakan sehari-hari, yaitu bahasa Sumbawa. Pembicaraan berjalan aman dan lancar. Tiba-tiba datang Upik kawan Tini yang merupakan orang Lombok. Untuk sesaat Upik tidak mengerti apa yang mereka katakan. Kemudian Tini memahami hal tersebut dan langsung beralih ke bahasa yang dapat dimengerti oleh Upik, yaitu bahasa Indonesia. kemudian Ia bercerita tentang apa yang Ia bicarakan dengan Tono dengan menggunakan bahasa Indonesia. 
Inilah yang disebut peristiwa alih kode. Jadi, kehadiran orang ketiga merupakan faktor yang mempengaruhi peristiwa alih kode.

Penyebab campur kode

Sama halnya dengan alih kode, campur kodepun disebabkan oleh masyarakat tutur yang multilingual. Namun, tidak seperti alih kode, campur kode tidak mempunyai maksud dan tujuan yang jelas untuk digunakan karena campur kode digunakan biasanya tidak disadari oleh pembicara atau dengan kata lain reflek pembicara atas pengetahuan bahasa asing yang diketahuinya.

(Ohoiwutun, 2007: 76) mengatakan campur kode digunakan karena apabila seseorang yang sedang dalam kegiatan berkomunikasi tidak mendapatkan padanan kata yang cocok yang dapat menjelaskan maksud dan tujuan yang sebenarnya, maka ia akan mencari padanan kata yang cocok dengan jalan mengambil istilah dari berbagai bahasa yang ia kuasai. Kemudian penyebab terjadinya campur kode dapat digolongkan menjadi dua, yaitu sikap (attitudinal type) yakni latar belakang sikap penutur, dan kebahasaan (linguistik type) yakni latar belakang keterbatasan bahasa, sehingga ada alasan identifikasi peranan, identifikasi ragam, dan keinginan untuk menjelaskan atau menafsirkan. Dengan demikian campur kode terjadi karena adanya hubungan timbal balik antara peranan penutur, bentuk bahasa, dan fungsi bahasa.

\section{Novel}

Secara etimologi, novel berasal dari bahasa Latin novellus yang diturunkan dari kata novles yang berarti baru. Novel dikatakan baru, karena muncul setelah puisi dan drama. Sedangkan menurut istilah, novel adalah suatu narasi yang panjang dan sering mengangkat kisah kehidupan manusia yang dibangun dari unsur instrinsik dan ekstrinsik. Kisah kehidupan itu bersifat rekaan, tetapi rasional. Sifat rasional yang dimiliki novel, dapat dilihat dari kemampuan pengarang melukiskan setiap peristiwa-peristiwa kehidupan secara rinci dan mengena, sehingga masuk akal untuk diterima pembaca. Pembaca yang membaca novel akan mendapatkan pelajaran hidup yang dapat dijadikan pedoman dan instropeksi diri. Selain itu, novel mampu mengungkap sejarah yang terjadi di masa lampau, sehingga memberi wawasan baru bagi pembaca.

Menurut Abrams (dalam

Nurgiyantoro, 2013:11-12) mengungkapkan bahwa secara harfiah novella berarti sebuah barang baru yang kecil, dan kemudian diartikan sebagai cerita pendek dalam bentuk prosa. Pendapat yang diungkapkan Abrams tampaknya cukup berbeda dengan yang diungkapkan oleh Semi. Semi (Susiati : 2016) mengemukakan novel sebagai suatu jenis karya sastra yang berbentuk naratif dan berkesinambungan ditandai oleh adanya aksi dan reaksi antar tokoh, khususnya antara antagonis dan protagonis. Tokoh antagonis dan protagonis memang akan selalu dihadirkan dalam novel. Kehadirannya akan memunculan berbagai persoalan (konflik) yang menimbulkan ketegangan dan rasa penasaran pembaca terhadap akhir cerita. Setiap cerita yang dihadirkan akan selalu berkaitan satu sama lain.

Oleh karenanya tidak berlebihan, jika novel dikatakan sebagai suatu karya yang membutuhkan konsentrasi tinggi dalam penggarapannya. Novel merupakan jenis sastra yang sedikit banyak memberikan gambaran tentang masalah kemasyarakatan. Novel tidak dapat dipisahkan dari gejolak atau keadaan masyarakat yang melibatkan penulis dan pembacanya Yudiono (Susiati: 2016). Pengertian tersebut mengandung arti, bahwa novel hadir sebagai hasil dari kegelisahan pengarang terhadap situasi dan kondisi yang terjadi di lingkungan masyarakat. Setiap peristiwa yang terjadi akan dipotret oleh pengarang. Potret kehidupan itu diambil dan dibentuk sedemikian menariknya oleh pengarang. Pengarang akan menggunakan segala kreatifitas yang dimilikinya untuk menggambarkan setiap sisi kehidupan 
masyarakat dalam novel. Sisi kehidupan masyarakat dalam novel sangat erat kaitannya dengan pengarang serta penikmat sastra, sehingga masyarakat berpengaruh juga terhadap perkembangan novel Erika (dalam Susiati 2016).

\section{Unsur Pembangun Novel}

Nurgiyantoro (2002) mengelompokan unsur-unsur pembangun sebuah novel yang kemudian membentuk sebuah totalitas itu disamping unsur formak bahasa, masih banyak lagi macamnya. Adapun pembagian unsur yang dimaksud adalah unsur instrinsik dan unsur ekstrinsik.

\section{Unsur Instrinsik}

Unsur instrinsik merupakan unsur-unsur yang membangun karya sastra itu sendiri. unsur-unsur inilah yang menyebabkan karya sastra hadir sebagai karya, unsur-unsur yang secara faktual akan dijumpai jika orang membaca karya sastra. Unsur instrinsik sebuah novel adalah unsur-unsur yang secara langsung turut serta membangun cerita.

Kepaduan antar unsur instrinsik inilah yang membuat sebuah novel berwujud. Hal-hal yang terkandung di dalam unsur inatrinsik sangat berkaitan erat dengan jiwa serta bathin para sastrawan. Hal ini merupakan kungkungan yang akhirnya akan mengalami peledakan spontan yang akan dituangkan dalam karya sastra itu. Halhal semacam itu mempengaruhi pengarang atau sastrawan dalam perwujudan imajinasinya.

Jika dilihat dari sudut kita pembaca, unsur-unsur cerita inilah yang akan kita jumpai jika kita membaca sebuah novel. Unsur yang dimaksud untuk menyebut sebagian saja, misalnya, peristiwa, cerita, plot, penokohan, tema, latar, sudut pandang penceritaan, bahasa atau gaya bahasa, dan lain-lain.

2. Unsur Ekstrinsik

Unsur ekstrinsik adalah unsur-unsur yang berada di luar karya sastra itu, tetapi secara tidak langsung mempengaruhi bangunan bangunan atau sistem organisme karya sastra. Atau secara lebih khusus ia dapat dikatakan sebagai unsurunsur yang mempengaruhi bangun cerita sebuah karya sastra, namun sendiri tidak ikut menjadi bagian didalamnnya. Walau demikian, unsur ekstrinsik cukup barpengaruh terhadap totalitas bangun cerita yang dihasilkan. Pemahaman unsur ekstrinsik suatu karya, bagaimanapun, akan membantu dalam hal pemahaman makna karya itu mengingat bahwa karya sastra tak muncul dari situasi kekosongan budaya.

Sebagaimana halnya unsur instrinsik, unsur ekstrinsik juga terdiri dari sejumlah unsur. Unsur-unsur yang dimaksud antara lain adalah keadaan subsektifitas individu yang memiliki sikap, keyakinan, pandangan hidup yang kesemuanya itu akan mempengaruhi karya yang ditulisnya. Unsur ekstrinsik berikutnya adalah psikologi pengarang, psikologi pembaca, maupun penerapan prinsip psikologi dalam karya. Keadaan dilingkungan pengarang seperti ekonomi, poitik, sosial juga akan berpengaruh terhadap karya sastra, dan hal itu merupakan unsur ekstrinsik pula.

Dari pengelompokkan unsur-unsur pembangun novel yang telah dijelaskan di atas maka penelaah terhadap majas atau gaya bahasa termasuk unsur pembangun novel yaitu pada unsur instrinsik. Sehingga unsur instrinsik yang secara langsung turut serta membangun cerita.

\section{METODE PENELITIAN \\ Pendekatan dan Jenis Penelitian}

Metode dalam penelitian ini adalah deskriptif kualitatif dilakukan dengan tidak mengutamakan angka-angka, tetapi mengutamakan kedalaman penghayatan terhadap interaksi antara konsep yang sedang dikaji secara impiris.

Adapun jenis penelitian ini, yaitu kepustakaan. Peneliti akan mendeskripsikan secara jelas kata, kalimat dan paragraf tentang alih kode dan campur kode yang 
terdapat dalam Novel Badai Matahari Andalusia Karya Hary El-Parsia.

\section{Sumber Data dan Jenis Data}

Sumber data dalam penelitian ini adalah Teks data tertulis yaitu Novel Badai Matahari Andalusia Karya Hary El-Parsia, Penerbit Diva Press Jakarta (Cetakan pertama, Januari 2013).

Data penelitian ini berupa kutipankutipan atau penggalan-penggalan teks yang berkaitan dengan alih kode dan campur kode yang terdapat pada Novel Badai Matahari Andalusia Karya Hary El-Parsia,

\section{Teknik Analisis Data}

Setelah data terkumpul, langkah yang ditempuh selanjutnya adalah menganalisis data tersebut berdasarkan prinsip-prinsip analisis data kualitatif. Dalam menganalisis data dalam penelitian ini, pendekatan yang digunakan adalah pendekatan objektif.

Pendekatan objektif adalah pendekatan yang memfokuskan perhatian kepada sastra itu sendiri. Pendekatan ini memandang karya sastra sebagai struktur yang otonom dan bebas dari hubungannya dengan realitas, pengarang, maupun pembaca.

Teknik analisis data yang digunakan peneliti adalah:

a. Membaca secara keseluruhan dan berulang-ulang novel yang dijadikan sebagai objek penelitian.

b. Mengidentifikasi bagian-bagian cerita dalam novel yang dijadikan sebagai obejek penelitian.

c. Mengidentifikasikan setiap data pada kelompok data yang sesuai dengan tujuan penelitian.

d. Mendeskripsikan (menggambarkan) datadata yang telah diklasifikasi.

e. Menyeleksi data sesuai dengan tujuan yang telah ditetapkan sebagai hasil penelitian.

\section{PEMBAHASAN (50\%) \\ Hasil Penelitian}

Setelah dianalisis dan dideskripsikan sesuai dengan analisis data dalam penelitian ini, terlihat Analisis Alih kode dan Campur kode Pada Novel Badai Matahari Andalusia Karya Hary El-Parsia sudah terlihat sejak awal sampai akhir cerita. Hampir seluruh bagian cerita memberikan gambar kedekatan kebahasaan. Hasil penelitian tentang Alih Kode dan Campur Kode Pada Novel Badai Matahari Andalusia Karya Hary El-Parsia. Untuk lebih jelasnya maka unsur tersebut akan diuraikan sebagai berikut:

Tabel Rekapan Alih kode dan Campur kode Pada Novel Badai Matahari Andalusia Karya Hary El-Parsia,

\begin{tabular}{|c|c|l|c|}
\hline No & Aspek & \multicolumn{1}{|c|}{ Halaman } & Frekuensi \\
\hline 1 & Alih kode & $\begin{array}{l}18,32,48,143, \\
178,288,357\end{array}$ & 7 \\
\hline 2 & $\begin{array}{l}\text { Campur } \\
\text { kode }\end{array}$ & $\begin{array}{l}21,42,82, \quad 165, \\
186, \quad 303,341, \\
397,385\end{array}$ & 9 \\
\hline \multicolumn{3}{|c|}{ Jumlah } & $\mathbf{1 6}$ \\
\hline
\end{tabular}

\section{Alih Kode Pada Novel Badai Matahari} Andalusia Karya Hary El-Parsia

Alih Kode Pada Novel Badai Matahari Andalusia Karya Hary ElParsia bisa direpresentasikan dengan gambaran tokoh-tokoh tersebut yang memiliki hubungan terhadap pengembangan tingkah lakunya. Dari penggambaran alih kode ini yang tidak lepas juga dari peralihan pemakaian dari suatu bahasa atau dialek ke bahasa atau dialek lainnya. Adapun aspek Alih Kode Pada Novel Badai Matahari Andalusia Karya Hary El-Parsia terdapat 7 kutipan sebagai berikut:

"Tidak terlalu lama, ia bergegas berdandan ala pelayan istana. Ia pakai gaun long dress merah dengan motif batik eropa klasik, yang mengekspos lekuk-lekuk tubuhnya yang indah tampak langsing, dengan coretan batik eropa klasik di gaunnya menambah dia lebih anggun". (Hal: 18) 
Berdasarkan kutipan di atas tampak dari kata long dress" kata tersebut merupakan kata Inggris yang diungkapkan untuk menunjukan keindahan kain atau pakaian mini (Ukuran Kecil). Dalam hal ini, digunakan sebagai ekspresi penghargaan, sementara dalam waktu yang sama juga sebagai karya atau motfi dunia dalam memamerkan kain dan gaun untuk wanita. Kata long dress tersebut merupakan penggambaran alih kode dari peralihan pemakaian suatu bahasa atau dialek ke bahasa atau dialek lainnya.

Istana itu berpoleskan kalimat " yesus my god", bertuliskan tinta emas, menghiasi tembok- tembok kerajaan dalam kemegahannya untuk singgasana sang raja. Atap istana terlihat indah setelah terkena pantulan sinar mentari dari ufuk timur kala musim panas. Mencorong tipis kuning keputihan saat dilihat dari atas gunung Gibraltar, bukit karang tempat pidatonya Thariq bin Ziyad. (Hal: 32)

Berdasarkan kutipan di atas tergambar alih kode yang ditandai oleh kalimat yesus my god yang memiliki arti yesus tuhanku merupakan kata Inggris yang mewakili suatu keyakinan umat kristiani, yang digunakan oleh kultur. Jadi Kata yesus my god tersebut merupakan penggambaran alih kode dari peralihan pemakaian suatu bahasa atau dialek ke bahasa atau dialek lainnya.

Ia ingin menggenggam ranah Andalusia di tampuk agama kristen. Ia juga tidak pernah minum bigbball. Bahkan dia sangat membencinya. (Hal: 48)

Berdasarkan kutipan di atas tampak kata bigbball yang memiliki arti minuman keras kata tersebut merupakan bahasa inggris yang digunakan oleh petutur dalam novel sebagai penggambaran pearlihan kode dari bahasa indonesia ke bahasa Inggris.

Lalu ia bersandar di bawah pohon bydestre yang rindang nan lebat daunnya. Ia panjatkan doa istimewanya dari relung hati sucinya, "ya Ilahi, tolong hamba yang kedinginan ini. Hangatkan tubuh hamba dengan selimut belas kasih-Mu. Wahai Allah Dzat Yang Menyayangi hamba-Nya, sabarkan hati hamba. (Hal: 288)

Kata bydestre merupakan kata Inggris yang digunakan untuk orang barat secara umum dan kristen secara khusus yang mempunyai arti Bunga Surga. Jadi Kata bydestre tersebut merupakan penggambaran alih kode dari peralihan pemakaian suatu bahasa atau dialek ke bahasa atau dialek lainnya.

Dalam do'a, ia mengutarakan keistimewaan para pejuang Fii Sabililah tiada pantas pahala hanyalah surga untuk mereka. Fatta juga berharap semoga menjadi bagian dari para pejuang yang diridhoi Allah SWT. (Hal: 143)

Berdasarkan kutipan di atas, bahwa kata Fii Sabililah merupakan kata Arab yang digunakan untuk orang arab secara umum dan umat Islam secara khusus, dan mempunyai arti jalan Allah. Jadi Kata Fii Sabililah tersebut merupakan penggambaran alih kode dari peralihan pemakaian suatu bahasa atau dialek ke bahasa atau dialek lainnya.

"Astaghfirullah," sahutnya tergugah gemetar. Pengawal itu memakai seragam dan senjata lengkap. Mereka menghampiri fatra. Salah satu prajurit memecah kekalutan pikirannya sembari menebar pujian dan hinaan. (Hal:178)

Berdasarkan kutipan di atas, bahwa kata Astaghfirullah merupakan kata Arab yang digunakan untuk orang arab secara umum dan umat Islam secara khusus, dan mempunyai arti Aku mohon ampun kepada allah yang Maha agung. Jadi Kata Astaghfirullah tersebut merupakan penggambaran alih kode dari peralihan pemakaian suatu bahasa atau dialek ke bahasa atau dialek lainnya.

Setelah selesai dalam renungan malam bersama doa istimewanya, fatra bangun 
seraya berkata, Allahu akbar." Seketika itu juga, pohon di sekitar gereja tertiup angin kencang. (Hal: 359)

Berdasarkan kutipan di atas, bahwa kata Allahu akbar" merupakan kata Arab yang diungkapkan untuk menunjukan kebesaran Allah, dalam hal arti kata Allahu Akbar yaitu Allah Maha Besar. Kata Allahu akbar tersebut merupakan penggambaran alih kode dari peralihan pemakaian suatu bahasa atau dialek ke bahasa atau dialek lainnya.

\section{Campur Kode Pada Novel Badai Matahari Andalusia Karya Hary El- Parsia}

Campur Kode Pada Novel Badai Matahari Andalusia Karya Hary ElParsia bisa direpresentasikan dengan gambaran tokoh-tokoh tersebut yang memiliki hubungan terhadap pengembangan tingkah lakunya. Dari penggambaran campur kode ini yang tidak lepas juga dari peralihan pemakaian dari suatu bahasa atau dialek ke bahasa atau dialek lainnya. Adapun aspek campur Kode Pada Novel Badai Matahari Andalusia Karya Hary ElParsia terdapat 9 kutipan sebagai berikut:

Dia menimpali penuh takzim," Abah, tolong doakan anakmu agar selamat fiddunya wal akhirah. Selamat dari kepungan Isabella yang membidikku. Hanya kekuatan doa orang tua yang dapat diijabah oleh Allah swt. Sebagai penyelamatku."(Hal: 21)

Berdasarkan kutipan di atas, bahwa kata fiddunya wal akhirah" merupakan kata arab yang terdiri dari frasa struktur yang memiliki arti dunia dan akhirat. Kata fiddunya wal akhirah tersebut merupakan penggambaran campur kode yaitu suatu keadaan berbahasa lain ialah bilamana orang mencampur dua (atau lebih) bahasa atau ragam bahasa dalam suatu tindak bahasa tanpa ada sesuatu dalam situasi berbahasa yang menuntut percampuran bahasa itu.
Wajahnya dipenuhi derai air mata. Badan dan bibirnya gemetar, takut bila fredich menghukum penggal. Ia beranggapan, jika mati di tempat orang oarang kafir, matinya su'ul khatimah.(Hal: 42)

Berdasarkan kutipan di atas, bahwa kata su'ul khatimah" merupakan kata arab yang terdiri dari frasa struktur yang memiliki arti akhir hidup yang buruk. Kata su'ul khatimah tersebut merupakan penggambaran campur kode yaitu suatu keadaan berbahasa lain ialah bilamana orang mencampur dua (atau lebih) bahasa atau ragam bahasa dalam suatu tindak bahasa tanpa ada sesuatu dalam situasi berbahasa yang menuntut percampuran bahasa itu.

"Darah mereka baunya harum sekali, aku sudah tidak sabar lagi membalas kematian mereka. Kita harus melawan. Bismillahi La haula wa la quwwata illa billah. Allahu Akbar!"'Hal: 82)

Berdasarkan kutipan di atas, bahwa kalimat Bismillahi La haula wa la quwwata illa billah merupakan kalimat arab yang terdiri dari frasa struktur yang memiliki arti Dengan nama allah, aku bertawakal kepada Allah, tidak ada daya dan kekuatan kecuali dengan-Nya. Kalimat Bismillahi La haula wa la quwwata illa billah tersebut merupakan penggambaran campur kode yaitu suatu keadaan berbahasa lain ialah bilamana orang mencampur dua (atau lebih) bahasa atau ragam bahasa dalam suatu tindak bahasa tanpa ada sesuatu dalam situasi berbahasa yang menuntut percampuran bahasa itu.

"Bulan itu juga ingin berbagi cerita tentang kisah kelam yang terjadi pada diri Ali Bin Abu Thalib karamallahu wajhah sang menantu Nabi Muhammad Saw" (Hal: 165)

Berdasarkan kutipan di atas, bahwa kalimat karamallahu wajhah merupakan kalimat arab yang terdiri dari frasa struktur yang memiliki arti Wajahnya tak pernah disujudkan kepada berhala. Kalimat karamallahu wajhah tersebut merupakan 
penggambaran campur kode yaitu suatu keadaan berbahasa lain ialah bilamana orang mencampur dua (atau lebih) bahasa atau ragam bahasa dalam suatu tindak bahasa tanpa ada sesuatu dalam situasi berbahasa yang menuntut percampuran bahasa itu.

"Hmm, agama islam itu agama yang tidak memaksa dan tiada paksaan, ada agamaku rahmatan lil 'alamin. (Hal: 186)

Berdasarkan kutipan di atas, bahwa kalimat rahmatan lil 'alamin merupakan kalimat arab yang terdiri dari frasa struktur yang memiliki arti Rahmat untuk alam semesta. Kalimat rahmatan lil 'alamin tersebut merupakan penggambaran campur kode yaitu suatu keadaan berbahasa lain ialah bilamana orang mencampur dua (atau lebih) bahasa atau ragam bahasa dalam suatu tindak bahasa tanpa ada sesuatu dalam situasi berbahasa yang menuntut percampuran bahasa itu.

"Allah sang Pemberi cinta dan penggenggam kerajaan cinta. Washallahu ala habibika saidina Muhammad shalallahu alaibi wa salam" (Hal: 303)

Berdasarkan kutipan di atas, bahwa kalimat Washallahu ala habibika saidina muhammad shalallahu alaibi wa salam merupakan kalimat arab yang terdiri dari frasa struktur yang memiliki arti Ya allah limpahkan sholawat untuk sayyidina muhammad dan keluarganya dan sahabatnya dan limpahkan baginya salam dan Semoga Allah memberikan sholawat dan salam kepadanya. Kalimat Washallahu ala habibika saidina muhammad shalallahu alaibi wa salam tersebut merupakan penggambaran campur kode yaitu suatu keadaan berbahasa lain ialah bilamana orang mencampur dua (atau lebih) bahasa atau ragam bahasa dalam suatu tindak bahasa tanpa ada sesuatu dalam situasi berbahasa yang menuntut percampuran bahasa itu.

Dalam kamusnya sekarang tertulis qalban wasi'a fil bahri habibullah. Hati seluas samudra cinta dalam naungan Ilahi.(Hal: 341)
Berdasarkan kutipan di atas, bahwa kalimat qalban wasi'a fil bahri habibullah merupakan kalimat arab yang terdiri dari frasa struktur yang memiliki arti Yang di nobatkan kepada laut bekerja memakmurkan cinta kepada allah. Kalimat qalban wasi'a fil bahri habibullah tersebut merupakan penggambaran campur kode yaitu suatu keadaan berbahasa lain ialah bilamana orang mencampur dua (atau lebih) bahasa atau ragam bahasa dalam suatu tindak bahasa tanpa ada sesuatu dalam situasi berbahasa yang menuntut percampuran bahasa itu.

\section{PENUTUP \\ Simpulan dan Saran}

Hasil analisis dan rekapan temuan analisis Alih Kode dan Campur Kode Pada Novel Badai Matahari Andalusia Karya Hary El-Parsia di atas dapat dikemukakan bahwa novel tersebut, mempunyai 399 halaman, namun hanya terdapat 16 kutipan secara totalitas Alih Kode dan Campur Kode. Selanjutnya Alih Kode dan Campur Kode yang paling dominan digunakan adalah campur Kode dengan mencampurkan bahasa Indonesia, bahasa Inggris bahasa arab. Dengan kata lain pengarang Hary ElParsia dalam karyanya lebih bamyak menggunakan Campur Kode sebagai ciri khas dari karyanya.

Kajian tersebut dapat dilakukan oleh peneliti selanjutnya dengan menggunakan teori sastra yang terkini pada objek-objek kajian sastra yang belum tuntas dibahas. Serta penulis menyarankan agar peneliti selanjutnya dapat melakukan penelitian dengan membandingkan kritik sosial kepengarangan antara dua pengarang yang berbeda.

\section{DAFTAR PUSTAKA}

Alwi, H., et al. (2000). Tata Bahasa Baku Bahasa Indonesia. Jakarta: Balai Pustaka.

Bachtiar, A., Oktaviantina, A.D., \& Rukmini. (2014). Ubrug: Kajian 
(UJSS) Vol. 1, No. 1, April 2020: 1-12

sosiolinguistik. Jurnal Sirok Bastra, 2(2), $121-128$.

Burhan, Nurgiantoro. 2013. Teori Pengkajian Fiksi. Yogyakarta: Gadjah Mada University Press.

Chaer, Abdul dan Leonie Agustina. 2004. Sosiolinguistik Perkenalan Awal. Jakarta: Rineka Cipta.

Hafid, A. \& Safar, M. (2007). Sejarah kota Kendari. Bandung: Humaniora.

Hastuti, H. B. P. (2013). Representasi perempuan Tolaki dalam mitos: Studi terhadap mitos Oheo dan mitos Wekoila. Tesis. Program Pascasarjana Universitas Halu Oleo, Kendari

Hemingway, Ernest. (2009). The Short Happy Life of Francis Macomber (Ulya Nataresmi, penerjemah dan Sandiantoro, editor). Surabaya: Selasar Surabaya Publishing. (Karya asli diterbitkan pada 1939).

Iye, R., \& Susiati, S. (2018). NILAI EDUKATIF DALAM NOVEL SEBAIT CINTA DI BAWAH LANGIT KAIRO KARYA MAHMUD JAUHARI ALI (Educative Values in Sebait Cinta di Bawah Langit Kairo by Mahmud Jauhari Ali). Sirok Bastra, 6 (2), 185191.

Susiati. 2016. Nilai-nilai Moral dalam Novel Negeri Lima Menara Karya A Fuadi. Jurnal Ilmu Sosial Welia Volume II. Baubau: Lembaga Bahasa Universitas Muhammadiyah Buton.

Komariyah, Siti. (2014). Isolek Jawa di pesisir selatan Banyuwangi, Jember, dan Lumajang. Jurnal Totobuang, 2(2), Edisi Desember 2014. 175-184. Kridalaksana, Harimurti. (2008). Kelas Kata dalam Bahasa Indonesia. Yogyakarta: Pustaka Pelajar.

Nababan, P.W.J. 2004. Sosioliguistik Suatu Pengajaran. Jakarta. Gramedia.

Ohoiwutun, Paul. 2007. Sosiolinguistik Memahami Bahasa dalam Konteks Masyarakat dan Kebudayaan. Jakarta : Kesaint Blanc.

Rahman, A. (2008, 23 Januari). Makna Mitos. Diperoleh dari http://www.esasterawan.net.

Rahardi, Kunjana. 2011. Sosioliguitik Kode dan Alih Kode. Yogyakarta: pustaka Pelajar.

Supriadi, A. (2010). Menyibak teori dan kritik sastra Islam [Resensi buku Teori dan kritikan sastra Malaysia dan Singapura, oleh A.R. Napiah]. Jurnal Metasastra, 3(2), 202-206.

Suamarsono dan Paina Partana. 2004. Sosiolinguistik. Yogyakarta: Sabda

Taufik. 2016. Campur Kode Penggunaan

Bahasa dan Sastra Indonesia Angkatan $2013 \quad$ Universitas Muhammdiyah Buton. Jurnal Ilmu Sosial Welia Volume II. Baubau: Lembaga Bahasa Universitas Muhammadiyah Buton.

Yamaguchi, R. (2012). Bahasa Melayu Makassar: Dulu, kini, dan masa depan. Dalam M. Yamaguchi (ed.), Aspekaspek bahasa daerah di Sulawesi bagian selatan (hlm. 119--131). Kyoto: Hokuto Publishing Inc. 